Article

\title{
Garcinol A Novel Inhibitor of Platelet Activation and Apoptosis
}

\author{
Hang Cao ${ }^{1,+}$, Abdulla Al Mamun Bhuyan ${ }^{1,+}$, Anja T. Umbach ${ }^{1}$, Ke Ma ${ }^{1}$, Oliver Borst ${ }^{2}$, \\ Meinrad Gawaz ${ }^{2}$, Shaqiu Zhang ${ }^{3}$, Bernd Nürnberg ${ }^{1}(\mathbb{D})$ and Florian Lang ${ }^{4, *}$ \\ 1 Department of Pharmacology \& Experimental Therapy, University of Tübingen, 72074 Tübingen, Germany \\ 2 Department of Cardiology and Cardiovascular Medicine, University Hospital of Tübingen, \\ 72076 Tübingen, Germany \\ 3 Institute of Preventive Veterinary Medicine, Sichuan Agricultural University, Wenjiang, \\ Chengdu 611130, China \\ 4 Department of Vegetative \& Clinical Physiology, University of Tübingen, 72074 Tübingen, Germany \\ * Correspondence: florian.lang@uni-tuebingen.de; Tel.: +49-7071-29-72194; Fax: +49-7071-29-5618 \\ + Both authors contributed equally and thus share first authorship.
}

Received: 11 April 2019; Accepted: 21 June 2019; Published: 1 July 2019

\begin{abstract}
Garcinol, an anti-inflammatory and anti-carcinogenic polyisoprenylated benzophenone isolated from Garcinia plants, stimulates tumor cell apoptosis and suicidal erythrocyte death, but supports the survival of hepatocytes and neurons. The present study explored whether the substance influences platelet function and/or apoptosis. To this end, we exposed murine blood platelets to garcinol ( $33 \mu \mathrm{M}, 30 \mathrm{~min})$ without and with activation by collagen-related peptide (CRP) $(2-5 \mu \mathrm{g} / \mathrm{mL})$ or thrombin $(0.01 \mathrm{U} / \mathrm{mL})$; flow cytometry was employed to estimate cytosolic $\mathrm{Ca}^{2+}$-activity $\left(\left[\mathrm{Ca}^{2+}\right]_{\mathrm{i}}\right)$ from Fluo-3 fluorescence, platelet degranulation from P-selectin abundance, integrin activation from $\alpha \mathrm{IIb} \beta 3$ integrin abundance, caspase activity utilizing an Active Caspase- 3 Staining kit, phosphatidylserine abundance from annexin-V-binding, relative platelet volume from forward scatter, and aggregation utilizing staining with CD9-APC and CD9-PE. As a result, in the absence of CRP and thrombin, the exposure of the platelets to garcinol did not significantly modify $\left[\mathrm{Ca}^{2+}\right]_{\mathrm{i}}$, P-selectin abundance, activated $\alpha \mathrm{IIb} \beta 3$ integrin, annexin-V-binding, cell volume, caspase activity, and aggregation. Exposure of platelets to CRP or thrombin was followed by a significant increase of $\left[\mathrm{Ca}^{2+}\right]_{\mathrm{i}}$, P-selectin abundance, $\alpha \mathrm{IIb} \beta 3$ integrin activity, annexin-V-binding, caspase activity, and aggregation, as well as significant cell shrinkage. All effects of CRP were strong and significant; those of thrombin were only partially and slightly blunted in the presence of garcinol. In conclusion, garcinol blunts CRP-induced platelet activity, apoptosis and aggregation.
\end{abstract}

Keywords: CRP; platelet activation; degranulation; integrin; cytosolic $\mathrm{Ca}^{2+}$ concentration; caspase; phosphatidylserine translocation

Key Contribution: The present study uncovers a novel powerful inhibitor of platelet activity; apoptosis and aggregation.

\section{Introduction}

Garcinol, a polyisoprenylated benzophenone [1,2] isolated from Garcinia cambogia [2] or Garcinia indica [1,3,4], counteracts oxidative stress and inflammation [3]. Garcinol is effective against several malignancies $[1,3]$ and favorably influences a variety of further clinical disorders such as cardiovascular disease, diabetes, gastric ailments, liver injury, allergy, and neurodegeneration $[1,3,5,6]$. Garcinol is effective against cancer in part by stimulating apoptosis [7-10], an effect paralleled by 
and presumably in part due to down-regulation of Akt [11], NFkB [12] and STAT3 [13], as well as activation of caspase 3 [14]. Garcinol has further been shown to counteract lipid peroxidation [2] and lipoxygenase activity [15]. Garcinol further stimulates the suicidal death of erythrocytes or eryptosis, an effect paralleled by oxidative stress and $\mathrm{Ca}^{2+}$ entry [16]. On the other hand, the putative effect on liver injury [6] and neurodegeneration [5] was attributed to inhibition of apoptosis.

Akt [17], NFKB [18,19], STAT3 [20], and caspases [21] are involved in generation, activation and apoptosis of blood platelets which contribute to primary hemostasis following vascular injury and by the same token contribute to the pathophysiology of acute thrombotic occlusion [22,23]. Disordered platelet function contributes to the pathophysiology of arterial thrombosis, vascular inflammation and atherogenesis $[23,24]$. Activation of platelets could be accomplished by an increase of cytosolic $\mathrm{Ca}^{2+}$ concentration $\left(\left[\mathrm{Ca}^{2+}\right]_{\mathrm{i}}\right)[25]$ due to $\mathrm{Ca}^{2+}$ release from intracellular stores [26] and subsequent activation of $\mathrm{Ca}^{2+}$ release-activated channel Orai1 in the plasma membrane [25,27-29]. Caspase activation triggers platelet apoptosis paralleled by cell shrinkage and cell membrane scrambling with phosphatidylserine translocation to the cell surface $[30,31]$.

To the best of our knowledge, an effect of garcinol on platelet activation and apoptosis has never been shown.

The present study thus explored whether garcinol influences platelet function and apoptosis prior to and following activation by CRP.

\section{Results}

The present study aimed to define the impact of garcinol on activation and apoptosis of blood platelets. To this end, murine platelets were isolated from wild type mice and incubated in Tyrode-HEPES buffer without or with activation by CRP in the absence and presence of garcinol.

Platelet degranulation was estimated from the increase of P-selectin abundance at the platelet surface, which was determined utilizing specific antibodies and flow cytometry. As illustrated in Figure 1A,C, without activation by CRP, the P-selectin abundance was negligible at the platelet surface and not significantly modified by garcinol $(2-33 \mu \mathrm{M})$ treatment. CRP significantly increased $\mathrm{P}$-selectin abundance, an effect significantly blunted in the presence of $33 \mu \mathrm{M}$ garcinol (Figure 1B,C). Lower concentrations of garcinol $(2$ and $17 \mu \mathrm{M})$ did not significantly modify the effect of CRP on P-selectin abundance.

Similarly, the abundance of active integrin $\alpha_{\mathrm{IIb}} \beta_{3}$ at the platelet surface was in the absence of CRP negligible (Figure 1D,F) and not significantly modified by garcinol $(2-33 \mu \mathrm{M})$ treatment. The abundance of active integrin $\alpha_{\mathrm{IIb}} \beta_{3}$ was significantly increased by CRP treatment. Again, the effect of CRP was significantly blunted in the presence of $33 \mu \mathrm{M}$ garcinol (Figure 1E,F), but not in the presence of 2 and $17 \mu \mathrm{M}$ garcinol.

Cytosolic $\mathrm{Ca}^{2+}$ concentration $\left(\left[\mathrm{Ca}^{2+}\right]_{\mathrm{i}}\right)$ was determined utilizing Fluo- 3 fluorescence. As illustrated in Figure 2A,C, without activation by CRP $\left[\mathrm{Ca}^{2+}\right]_{i}$ was similarly low in the absence and presence of garcinol. The histogram may, however, point to some minor increase of the fluorescence variability following garcinol treatment of resting blood platelets (Figure 2A). In any case, activation by CRP was followed by a significant increase of $\left[\mathrm{Ca}^{2+}\right]_{i}$ in platelets, an effect significantly blunted in the presence of garcinol (Figure 2B,C).

Phosphatidylserine abundance was estimated from annexin-V-binding. As illustrated in Figure $3 \mathrm{~A}, \mathrm{C}$, the percentage of annexin- $\mathrm{V}$ positive platelets was again negligible in the absence of CRP, irrespective of the presence or absence of $33 \mu \mathrm{M}$ garcinol. CRP significantly enhanced the percentage of annexin- $\mathrm{V}$ binding platelets, an effect again significantly blunted in the presence of $33 \mu \mathrm{M}$ garcinol (Figure $3 \mathrm{~B}, \mathrm{C}$ ). 

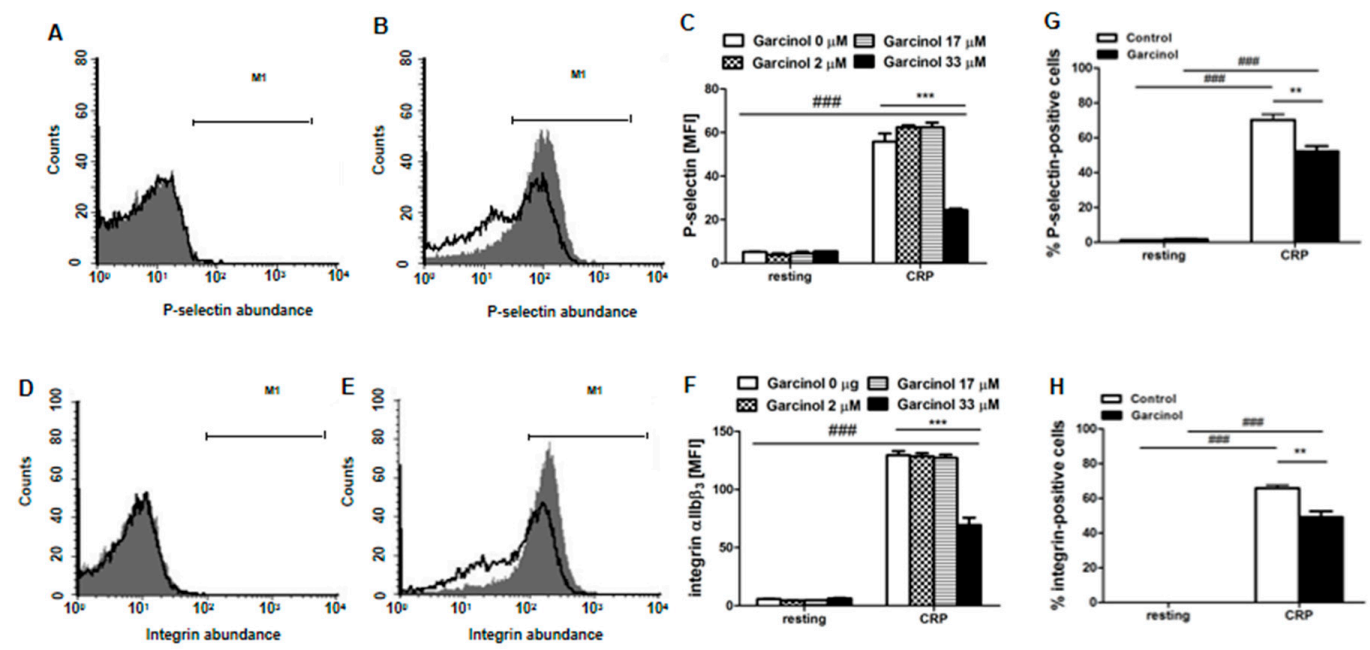

Figure 1. Garcinol-sensitive CRP-induced platelet degranulation and integrin $\alpha_{\mathrm{IIb}} \beta_{3}$ activation. (A,B) Original histogram overlays of P-selectin-related fluorescence in murine platelets without (A) and with (B) a $15 \mathrm{~min}$ CRP $(2 \mu \mathrm{g} / \mathrm{mL})$ treatment without (grey areas) and with (black lines) presence of garcinol $(33 \mu \mathrm{M}, 30 \mathrm{~min})$. (C) Arithmetic means \pm SEM $(n=4)$ of the P-selectin-related fluorescence (arbitrary units) in murine platelets without (left bars) and with (right bars) a 15-min CRP treatment $(2 \mu \mathrm{g} / \mathrm{mL})$ in the presence of $0-33 \mu \mathrm{M}$ garcinol. $(\mathbf{D}, \mathbf{E})$ Original histogram overlays of activated $\alpha_{\text {IIb }} \beta_{3}$ integrin-related fluorescence in murine platelets without (D) and with (E) a 15-min CRP $(2 \mu \mathrm{g} / \mathrm{mL})$ treatment without (grey areas) and with (black lines) presence of garcinol ( $33 \mu \mathrm{M}, 30 \mathrm{~min})$. (F) Arithmetic means \pm SEM $(n=4)$ of activated $\alpha_{\mathrm{IIb}} \beta_{3}$ integrin-related fluorescence (arbitrary units) in murine platelets without (left bars) and with (right bars) a 15-min CRP treatment $(2 \mu \mathrm{g} / \mathrm{mL})$ in the presence of 0-33 $\mu \mathrm{M}$ garcinol. $(\mathbf{G}, \mathbf{H})$ Arithmetic means \pm SEM $(n=4)$ of the percentage of P-selectin-positive $(\mathrm{G})$ and of activated $\alpha_{I I b} \beta_{3}$ integrin-positive $(\mathrm{H})$ murine platelets in the absence (white bars) and presence (black bars) of $33 \mu \mathrm{M}$ garcinol without (left bars) and with (right bars) a 15-min CRP treatment $(2 \mu \mathrm{g} / \mathrm{mL})$. \#\#\# $(p<0.001)$ indicates statistically significant difference from the absence of CRP; ${ }^{* *}(p<0.01)$ and $* * *(p<0.001)$ indicate statistically significant difference from absence of garcinol.
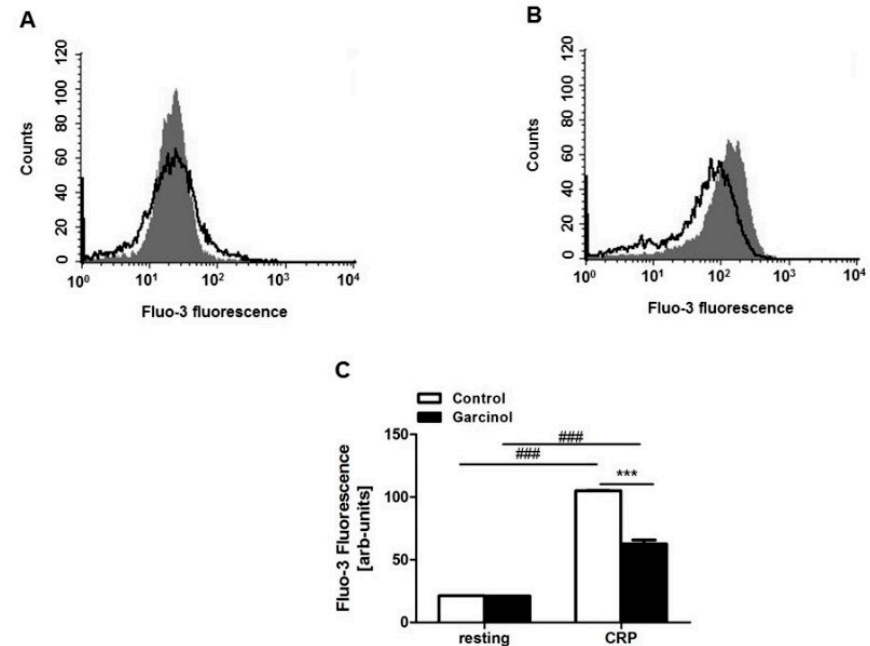

Figure 2. Garcinol-sensitive CRP-induced increase of cytosolic $\mathrm{Ca}^{2+}$ concentration. (A,B) Original histogram overlays of Fluo-3 fluorescence reflecting cytosolic $\mathrm{Ca}^{2+}$ activity in murine platelets without (A) and with (B) a $150 \mathrm{~s}$ treatment with CRP $(2 \mu \mathrm{g} / \mathrm{mL})$ without (grey areas) and with (black lines) presence of garcinol (33 $\mu \mathrm{M}, 30 \mathrm{~min})$. (C) Arithmetic means \pm SEM $(n=4)$ of Fluo-3 fluorescence reflecting cytosolic $\mathrm{Ca}^{2+}$ activity in murine platelets without (left bars) and with (right bars) a $150 \mathrm{~s}$ CRP treatment in the absence (white bars) and presence (black bars) of $33 \mu \mathrm{M}$ garcinol. \#\#\# ( $p<0.001)$ indicates statistically significant difference from absence of CRP; ${ }^{* * *}(p<0.001)$ indicates statistically significant difference from absence of garcinol. 

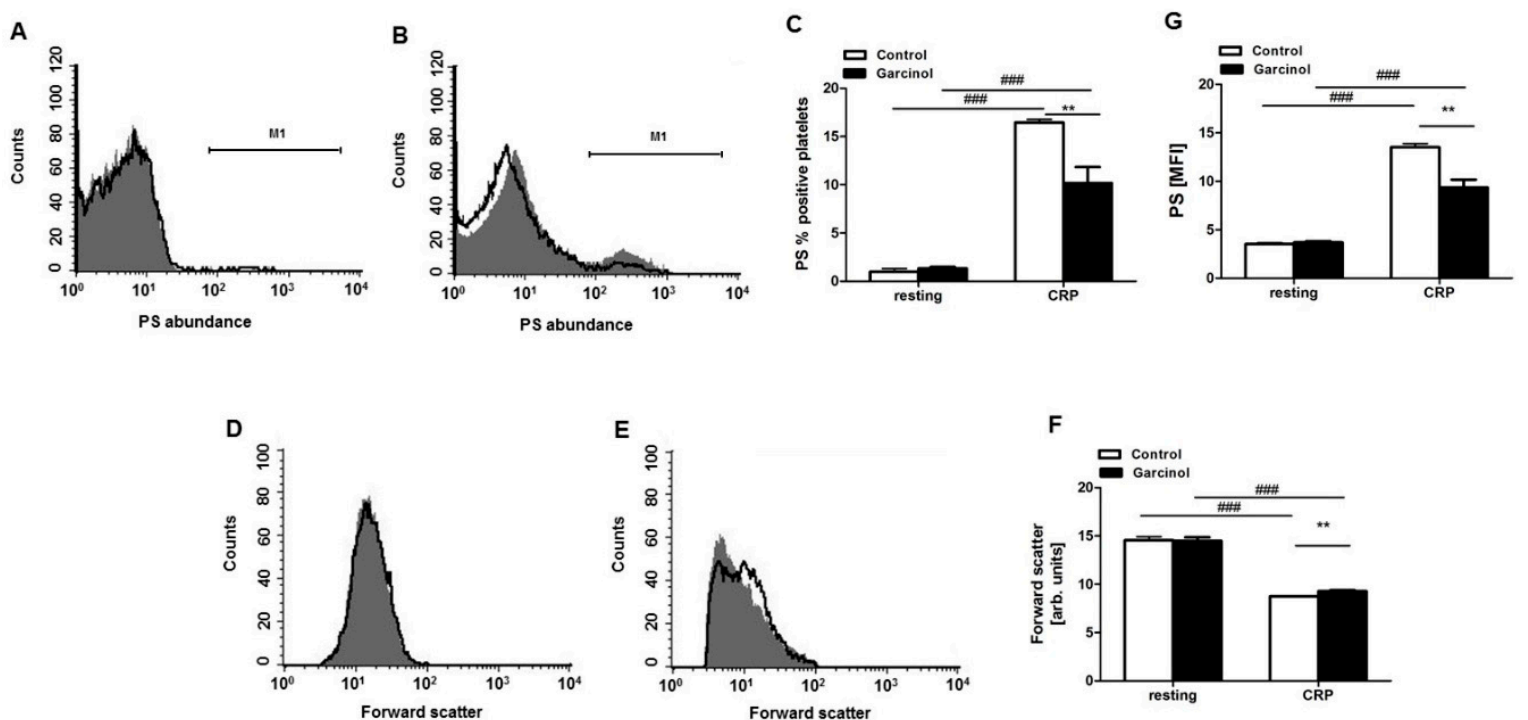

Figure 3. Garcinol-sensitive CRP-dependent cell membrane scrambling and cell shrinkage. (A,B) Original histogram overlays of annexin-V-binding reflecting phosphatidylserine abundance at the surface of murine platelets without (A) and with (B) a 10-min treatment with CRP $(5 \mu \mathrm{g} / \mathrm{mL})$ without (grey areas) and with (black lines) presence of garcinol (33 $\mu \mathrm{M}, 30 \mathrm{~min})$. (C) Arithmetic means \pm SEM $(n=4)$ of the percentage of annexin-V-binding murine platelets in the absence (white bars) and presence (black bars) of $33 \mu \mathrm{M}$ garcinol without (left bars) and with (right bars) a 10 min CRP treatment $(5 \mu \mathrm{g} / \mathrm{mL})$. (D,E) Original histogram overlays of forward scatter reflecting cell volume of murine platelets without (D) and with (E) a 10-min treatment with CRP (5 $\mathrm{\mu g} / \mathrm{mL})$ without (grey areas) and with (black lines) presence of garcinol ( $33 \mu \mathrm{M}, 30 \mathrm{~min})$. (F) Arithmetic means \pm SEM $(n=4)$ of forward scatter reflecting cell volume of murine platelets without (left bars) and with (right bars) a 10-min CRP treatment $(5 \mu \mathrm{g} / \mathrm{mL})$ in the absence (white bars) and presence (black bars) of $33 \mu \mathrm{M}$ garcinol. (G) Arithmetic means \pm SEM $(n=4)$ of annexin-V-binding in murine platelets without (left bars) and with (right bars) a 10-min CRP $(5 \mu \mathrm{g} / \mathrm{mL})$ treatment in the absence (white bars) and presence (black bars) of $33 \mu \mathrm{M}$ garcinol. \#\# ( $p<0.001)$ indicates statistically significant difference from absence of CRP; ** $(p<0.01)$ indicates statistically significant difference from absence of garcinol.

Platelet volume was estimated from forward scatter, which was determined by flow cytometry. As illustrated in Figure 3D,F, in the absence of CRP, platelet volume was similar in the absence and presence of $33 \mu \mathrm{M}$ garcinol. Activation of the platelets by CRP was followed by a marked decrease of forward scatter, an effect slightly but significantly blunted in the presence of $33 \mu \mathrm{M}$ garcinol (Figure 3E,F).

A kit has been used for the detection of activated caspase 3. As illustrated in Figure 4A,C, without activation by CRP, caspase activity was negligible, irrespective of the presence of garcinol. CRP significantly enhanced caspase activity, an effect again significantly blunted in the presence of $33 \mu \mathrm{M}$ garcinol (Figure 4B-D).

To elucidate the effect of CRP and garcinol on platelet aggregation, platelets were labeled with two distinct dyes and the coincidence of the two dyes (number of dots in Q2) estimated by flow cytometry. As illustrated in Figure $5 \mathrm{Aa}, \mathrm{Ab}, \mathrm{B}$, without activation by CRP platelet aggregation was similarly low in the absence and presence of $33 \mu \mathrm{M}$ garcinol. CRP treatment significantly increased platelet aggregation as reflected by the number of dots in Q2 (Figure $5 \mathrm{Ac}, \mathrm{B}$ ). The effect was significantly blunted by $33 \mu \mathrm{M}$ garcinol (Figure 5Ad,B).

An additional series of experiments explored whether garcinol similarly interferes with the effect of thrombin on blood platelets. As a result, thrombin $(0.01 \mathrm{U} / \mathrm{mL})$ treatment was followed by a sharp increase of P-selectin surface abundance (Figure 6A) of active integrin $\alpha_{\mathrm{IIb}} \beta_{3}$ abundance (Figure 6B), of caspase-3 activity (Figure 6C) and percentage of annexin-V binding platelets (Figure 6D), effects only slightly blunted by garcinol $(33 \mu \mathrm{M})$. The effect of garcinol reached statistical significance only at the 
effect of thrombin on P-selectin surface abundance and active integrin $\alpha_{\mathrm{IIb}} \beta_{3}$ abundance. Thrombin $(0.01 \mathrm{U} / \mathrm{mL})$ treatment was further followed by platelet shrinkage (Figure $6 \mathrm{E}$ ), an effect not significantly modified by treatment with garcinol $(33 \mu \mathrm{M})$.

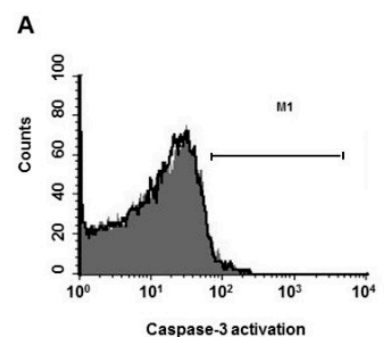

C

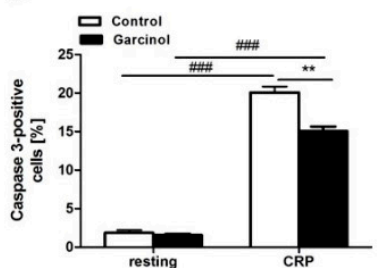

B

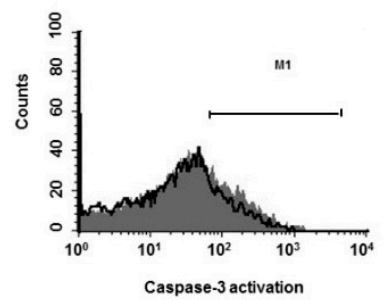

D

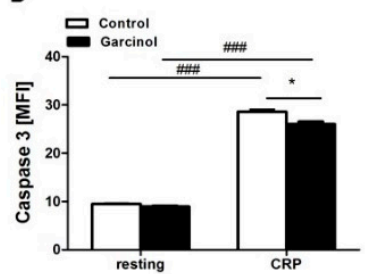

Figure 4. Garcinol-sensitive CRP-induced increase of caspase-3 activity. (A,B) Original histogram overlays of fluorescence reflecting caspase-3 activity in murine platelets without (A) and with (B) a 10-min treatment with CRP $(5 \mu \mathrm{g} / \mathrm{mL})$ without (grey areas) and with (black lines) presence of garcinol (33 $\mu \mathrm{M}, 30 \mathrm{~min})$. (C) Arithmetic means \pm SEM $(n=4)$ of the percentage of caspase-3-FITC-positive murine platelets in the absence (white bars) and presence (black bars) of $33 \mu \mathrm{M}$ garcinol without (left bars) and with (right bars) a 10-min CRP treatment $(5 \mu \mathrm{g} / \mathrm{mL})$. (D) Arithmetic means \pm SEM $(n=4)$ of caspase-3-FITC-related fluorescence of murine platelets in the absence (white bars) and presence (black bars) of $33 \mu \mathrm{M}$ garcinol without (left bars) and with (right bars) a 10-min CRP treatment $(5 \mu \mathrm{g} / \mathrm{mL})$. \#\#\# ( $p<0.001)$ indicates statistically significant difference from absence of CRP, ${ }^{*}(p<0.05){ }^{* *}(p<0.01)$ indicate statistically significant difference from absence of garcinol.

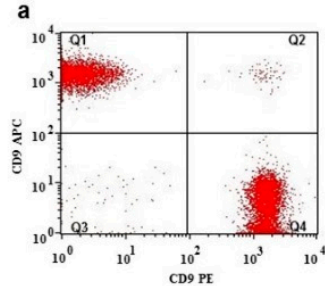

$$
\text { C }
$$

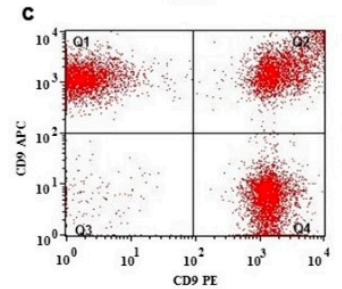

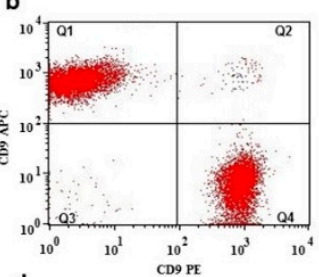

d

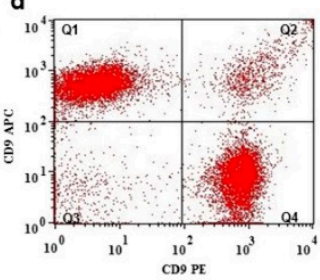

B

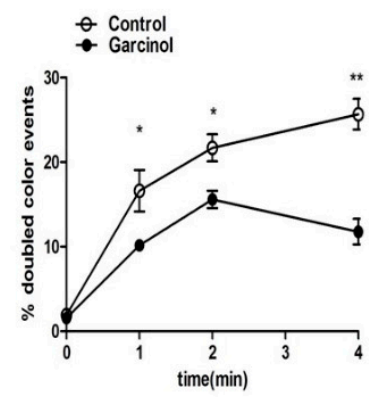

Figure 5. Garcinol-sensitive CRP-induced platelet aggregation. (A) Original dot blots reflecting platelet aggregation without $(\mathbf{a}, \mathbf{c})$ and with $(\mathbf{b}, \mathbf{d})$ prior garcinol $(33 \mu \mathrm{M})$ treatment, and subsequent treatment with CRP $(2 \mu \mathrm{g} / \mathrm{mL})$ for $0 \mathrm{~min}(\mathrm{a}, \mathrm{b})$ and $4 \mathrm{~min}(\mathrm{c}, \mathrm{d})$. (B) Arithmetic means $\pm \operatorname{SEM}(n=4)$ of platelet aggregation without (white circles) and with (black circles) prior garcinol $(33 \mu \mathrm{M})$ treatment as a function of time after addition of CRP $(2 \mu \mathrm{g} / \mathrm{mL}) .(p<0.05)$ and ${ }^{* *}(p<0.01)$ indicates a statistically significant difference from absence of garcinol. 

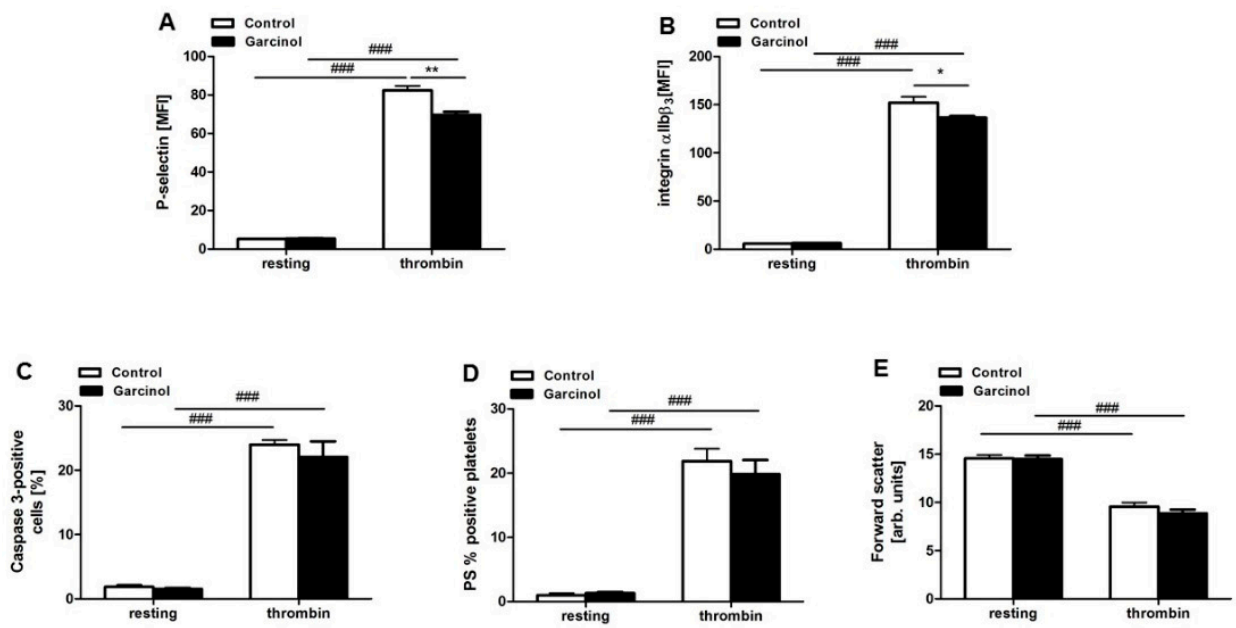

Figure 6. Effect of thrombin on P-selectin surface abundance, active integrin $\alpha_{\mathrm{IIb}} \beta_{3}$ abundance, caspase-3 activity, cell membrane scrambling, and cell volume in absence and presence of garcinol. Arithmetic means \pm SEM $(n=4)$ of (A) P-selectin surface abundance, (B) active integrin $\alpha_{\text {IIb }} \beta_{3}$ abundance, (C) caspase-3 activity, (D) annexin-V-binding, and (E) forward scatter prior to (resting) or 10-15 min following treatment with $0.01 \mathrm{U} / \mathrm{mL}$ thrombin in the absence (white bars) and presence (black bars) of garcinol $(33 \mu \mathrm{M}, 30 \mathrm{~min})$. \#\#\# ( $p<0.001)$ indicates statistically significant difference from absence of thrombin; ${ }^{*}(p<0.05)$ and ${ }^{* *}(p<0.01)$ indicate statistically significant difference from absence of garcinol.

\section{Discussion}

The present observations disclose a novel powerful inhibitor of platelet activation and apoptosis. Treatment of murine blood platelets by garcinol significantly blunts the effect of CRP on $\left[\mathrm{Ca}^{2+}\right]_{\mathrm{i}}$, P-selectin abundance, $\alpha_{\mathrm{IIb}} \beta_{3}$ integrin activity, annexin-V-binding, cell volume, caspase activity, and aggregation. In the absence of CRP, garcinol had no appreciable effect on those parameters.

The observed effects of garcinol on platelet activation and apoptosis are at least in part due to a blunting of the CRP-induced increase of cytosolic $\mathrm{Ca}^{2+}$ activity $\left(\left[\mathrm{Ca}^{2+}\right]_{\mathrm{i}}\right)$, a key event in platelet activation $[18,28]$. Excessive increase of $\left[\mathrm{Ca}^{2+}\right]_{\mathrm{i}}$ with subsequent over-activity of platelets fosters the development of arterial thrombosis [32]. An increase of $\left[\mathrm{Ca}^{2+}\right]_{\mathrm{i}}$ is further a powerful stimulator of cell membrane phospholipid scrambling with translocation of phosphatidylserine to the platelet surface [24,33-35]. Phosphatidylserine exposure at the platelet surface is part of the pro-coagulant function of platelets and thus participates in the orchestration of hemostasis [36]. Moreover, phosphatidylserine-exposing platelets are bound to and engulfed by macrophages [37].

The present paper did not address the signaling accounting for the effect of garcinol on $\left[\mathrm{Ca}^{2+}\right]_{\mathrm{i}}$. In tumor cells, garcinol is in part effective by down-regulation of Akt [11] and NFkB [12]. Both, Akt [17] and $N F \kappa B[18,19]$ participate in the regulation of platelet function. NFKB is known to up-regulate Orai1 [18], the major $\mathrm{Ca}^{2+}$ entry pathway into platelets [25,27-29]. However, it must be kept in mind that mature platelets lack nuclei and their function and survival could not be regulated by transcription.

Garcinol had negligible or no effects on the stimulation of platelets by thrombin. The signaling of thrombin differs from that of CRP. CRP is effective through (GP)VI-dependent signaling pathway [38], whereas thrombin is effective through G-protein coupled receptors [39].

In view of the present data, it is tempting to speculate that garcinol and related substances may be employed for the inhibition of platelet activation in the prophylaxis and/or treatment of thrombosis. Garcinol is a food additive which could be administrated to patients [40]. It must be kept in mind, though, that the present in-vitro studies in murine platelets cannot be translated without reservations into in-vivo effects on functions of human platelets. Clearly, additional experimental efforts are needed to define the effect of garcinol on platelet function in patients. 


\section{Conclusions}

In isolated murine platelets, garcinol is a powerful inhibitor of CRP-induced increase of P-selectin abundance, $\alpha_{\mathrm{IIb}} \beta_{3}$ integrin activity, annexin-V-binding, caspase activity, and aggregation; and thus, it counteracts platelet activation and apoptosis. Garcinol is at least in part effective by increasing $\left[\mathrm{Ca}^{2+}\right]_{\mathrm{i}}$. In contrast, garcinol is only a weak inhibitor of thrombin-induced platelet stimulation. Additional effort is needed defining in vivo garcinol effects prior to considering the substance for prophylaxis/treatment of thrombosis in patients.

\section{Materials and Methods}

\subsection{Mice}

All animal experiments were conducted according to the German law for the welfare of animals and were approved by the authorities of the state of Baden-Württemberg (Regierungspräsidium Tübingen according to \$4,19 December 2011). Experiments were performed with blood platelets isolated from wild type mice. The mice had free access to water and control chow (Ssniff, Soest, Germany) [40-46].

\subsection{Preparation of Mouse Platelets}

Platelets were prepared as described previously [40-46]. Platelets were obtained from 10to 12 -week-old mice of either sex. The mice were anesthetized, and $800 \mu \mathrm{L}$ blood was drawn from the retro-orbital plexus into tubes with $200 \mu \mathrm{L}$ acid-citrate-dextrose buffer before the mice were sacrificed [47]. Platelet-rich plasma (PRP) was obtained by centrifugation at $260 \mathrm{~g}$ for $5 \mathrm{~min}$. Afterwards, PRP was centrifuged at $640 \mathrm{~g}$ for $5 \mathrm{~min}$ to pellet the platelets. Where necessary, apyrase $(0.02 \mathrm{U} / \mathrm{mL}$; Sigma-Aldrich) and prostaglandin $\mathrm{I}_{2}(0.5 \mu \mathrm{M}$; Calbiochem, Darmstadt, Germany) were added to the PRP to prevent the activation of platelets during isolation [48]. After two washing steps, the pellet of washed platelets was resuspended in modified Tyrode-HEPES buffer ( $\mathrm{pH}$ 7.4, supplemented with $1 \mathrm{mM}$ $\mathrm{CaCl}_{2}$ ). Where indicated, collagen-related peptide (Roche, Basel, Switzerland) or thrombin (Roche, Basel, Switzerland) were added at the indicated concentrations [49]. Platelets have been pre-incubated with 0-33 $\mu \mathrm{M}$ garcinol (R\&D, Wiesbaden, Germany) for $30 \mathrm{~min}$ at $37^{\circ} \mathrm{C}$ before stimulation.

\subsection{Cytosolic Calcium}

For the measurement of the cytosolic $\mathrm{Ca}^{2+}$ concentration, the platelet preparation was washed once in Tyrode buffer (pH 7.4), stained with $3 \mu$ M Fluo-3AM (Biotinium, USA) in the same buffer and incubated at $37^{\circ} \mathrm{C}$ for $30 \mathrm{~min}$. Following the indicated experimental treatment, relative fluorescence was measured utilizing a BD FACS Calibur (BD Biosciences, Heidelberg, Germany) [41-46,50].

\subsection{P-Selectin and Activated Integrin Abundance}

Fluorophore-labeled antibodies were utilized for the detection of P-selectin expression (Wug.E9-FITC) [51] and the active form of $\alpha_{\mathrm{IIb}} \beta_{3}$ integrin (JON/A-PE) [52]. Washed mouse platelets $\left(1 \times 10^{6}\right)$ were suspended in modified Tyrode buffer $\left(\mathrm{pH}\right.$ 7.4) containing $1 \mathrm{mM} \mathrm{CaCl}_{2}$ and antibodies (1:10 dilution) and subsequently subjected to the respective treatments and for the indicated time periods at room temperature (RT). The reaction was stopped by the addition of PBS and the samples were immediately analyzed on a BD FACSCalibur [24,41-46].

\subsection{Phosphatidylserine Exposure and Forward Scatter}

For the determination of phosphatidylserine exposure, the platelet preparation was centrifuged at $660 \mathrm{~g}$ for $5 \mathrm{~min}$ followed by washing once with Tyrode buffer (pH 7.4) with $1 \mathrm{mM} \mathrm{CaCl}_{2}$, staining with 1:20 dilution of Annexin-V-FITC (Mabtag, Friesoythe, Germany) in Tyrode buffer (pH 7.4) with $2 \mathrm{mM} \mathrm{CaCl} 2$ and incubation at $37^{\circ} \mathrm{C}$ for $30 \mathrm{~min}$. Annexin-V-binding reflecting surface exposure 
of phosphatidylserine was evaluated by flow cytometry utilizing a BD FACSCalibur. In parallel, the forward scatter (FSC) of the platelets was determined by flow cytometry as a measure of platelet size [41-46,53].

\subsection{Caspase-3 Activity}

Caspase 3 activity was determined utilizing a CaspGlow Fluorescein Active Caspase-3 Staining kit from BioVision (Milpitas, CA, USA) according to the manufacturer's instruction. Fluorescence intensity was measured at an excitation wavelength of $488 \mathrm{~nm}$ and an emission wavelength of $530 \mathrm{in}$ a BD FACSCalibur (BD Biosciences, USA) [41-46].

\subsection{Platelet Aggregation}

Aggregation was determined utilizing flow cytometry as previously described [54]. To this end, platelets were labeled either with CD9-APC or with CD9-PE monoclonal antibodies (1:100 dilution, Abcam) for $15 \mathrm{~min}$ at room temperature. Following incubation, differently labeled platelet samples were washed twice, mixed 1:1, and incubated in $33 \mu \mathrm{M}$ garcinol (R\&D, Germany) for $30 \mathrm{~min}$ at $37^{\circ} \mathrm{C}$ while shaking at $600 \mathrm{rpm}$ for $10 \mathrm{~min}$. Pre-incubated platelets were activated with $2 \mu \mathrm{g} / \mathrm{mL} \mathrm{CRP} \mathrm{at} 37^{\circ} \mathrm{C}$ while shaking at $1000 \mathrm{rpm}$. At the indicated time points, samples were fixed by the addition of $0.5 \%$ paraformaldehyde (Carl Roth, Karlsruhe, Germany) in phosphate-buffered saline. The fixed samples were measured utilizing a BD FACSCalibur (BD Biosciences, Heidelberg, Germany). For quantification, a quadrant was set in the dot plot of respective channels on non-stimulated platelets [41-43,46,49].

\subsection{Statistical Analysis}

Data are provided as means \pm SEM; $n$ represents the number of independent experiments. All data were tested for significance using ANOVA with Tukey's test as post-test or unpaired student's $t$-test as appropriate. Results with $p<0.05$ were considered statistically significant [41-46].

Author Contributions: H.C., A.A.M.B., A.T.U., K.M. performed experiments and evaluated the data, F.L., O.B., M.G., S.Z., B.N. designed experiments and F.L. drafted and wrote the manuscript. All authors corrected, read and approved the manuscript.

Funding: This project was supported by the Deutsche Forschungsgemeinschaft (Klinische ForschungsgruppeKFO-274: "Platelets-Molecular Mechanisms and Translational Implications") and by the Deutsche Forschungsgemeinschaft (DFG, German Research Foundation)-Project number 374031971-TRR 240, by the DFG grant "Gi proteins and platelets" (NU 53/13-1), by the Institutional Strategy of the University of Tuebingen (Deutsche Forschungsgemeinschaft, ZUK63), and by the Open Access Publishing Fund of Tuebingen University.

Acknowledgments: The authors acknowledge the meticulous preparation of the manuscript by Lejla Subasic. The sponsor(s) had no role in study design, the collection, analysis and interpretation of data, in the writing of the report, and in the decision to submit the article for publication.

Conflicts of Interest: The authors declare no conflict of interest.

\section{References}

1. Behera, A.K.; Swamy, M.M.; Natesh, N.; Kundu, T.K. Garcinol and its role in chronic diseases. Adv. Exp. Med. Biol. 2016, 928, 435-452. [PubMed]

2. Kolodziejczyk, J.; Masullo, M.; Olas, B.; Piacente, S.; Wachowicz, B. Effects of garcinol and guttiferone k isolated from garcinia cambogia on oxidative/nitrative modifications in blood platelets and plasma. Platelets 2009, 20, 487-492. [CrossRef] [PubMed]

3. Liu, C.; Ho, P.C.; Wong, F.C.; Sethi, G.; Wang, L.Z.; Goh, B.C. Garcinol: Current status of its anti-oxidative, anti-inflammatory and anti-cancer effects. Cancer Lett. 2015, 362, 8-14. [CrossRef] [PubMed]

4. Padhye, S.; Ahmad, A.; Oswal, N.; Sarkar, F.H. Emerging role of garcinol, the antioxidant chalcone from garcinia indica choisy and its synthetic analogs. J. Hematol. Oncol. 2009, 2, 38. [CrossRef] [PubMed]

5. Hao, F.; Jia, L.H.; Li, X.W.; Zhang, Y.R.; Liu, X.W. Garcinol upregulates gabaa and gad65 expression, modulates bdnf-trkb pathway to reduce seizures in pentylenetetrazole (ptz)-induced epilepsy. Med. Sci. Monit. 2016, 22, 4415-4425. [CrossRef] [PubMed] 
6. Jing, Y.; Ai, Q.; Lin, L.; Dai, J.; Jia, M.; Zhou, D.; Che, Q.; Wan, J.; Jiang, R.; Zhang, L. Protective effects of garcinol in mice with lipopolysaccharide/d-galactosamine-induced apoptotic liver injury. Int. Immunopharmacol. 2014, 19, 373-380. [CrossRef] [PubMed]

7. Aggarwal, S.; Das, S.N. Garcinol inhibits tumour cell proliferation, angiogenesis, cell cycle progression and induces apoptosis via nf-kappab inhibition in oral cancer. Tumour Biol. 2016, 37, 7175-7184. [CrossRef] [PubMed]

8. Ahmad, A.; Wang, Z.; Wojewoda, C.; Ali, R.; Kong, D.; Maitah, M.Y.; Banerjee, S.; Bao, B.; Padhye, S.; Sarkar, F.H. Garcinol-induced apoptosis in prostate and pancreatic cancer cells is mediated by nf-kappab signaling. Front. Biosci. 2011, 3, 1483-1492. [CrossRef]

9. Cheng, A.C.; Tsai, M.L.; Liu, C.M.; Lee, M.F.; Nagabhushanam, K.; Ho, C.T.; Pan, M.H. Garcinol inhibits cell growth in hepatocellular carcinoma hep3b cells through induction of ros-dependent apoptosis. Food Funct. 2010, 1, 301-307. [CrossRef]

10. Parasramka, M.A.; Gupta, S.V. Synergistic effect of garcinol and curcumin on antiproliferative and apoptotic activity in pancreatic cancer cells. J. Oncol. 2012, 2012, 709-739. [CrossRef]

11. Liao, C.H.; Sang, S.; Ho, C.T.; Lin, J.K. Garcinol modulates tyrosine phosphorylation of fak and subsequently induces apoptosis through down-regulation of src, erk, and akt survival signaling in human colon cancer cells. J. Cell. Biochem. 2005, 96, 155-169. [CrossRef] [PubMed]

12. Ahmad, A.; Wang, Z.; Ali, R.; Maitah, M.Y.; Kong, D.; Banerjee, S.; Padhye, S.; Sarkar, F.H. Apoptosis-inducing effect of garcinol is mediated by nf-kappab signaling in breast cancer cells. J. Cell. Biochem. 2010, 109, 1134-1141. [PubMed]

13. Sethi, G.; Chatterjee, S.; Rajendran, P.; Li, F.; Shanmugam, M.K.; Wong, K.F.; Kumar, A.P.; Senapati, P.; Behera, A.K.; Hui, K.M.; et al. Inhibition of stat3 dimerization and acetylation by garcinol suppresses the growth of human hepatocellular carcinoma in vitro and in vivo. Mol. Cancer 2014, 13, 66. [CrossRef] [PubMed]

14. Hong, J.; Kwon, S.J.; Sang, S.; Ju, J.; Zhou, J.N.; Ho, C.T.; Huang, M.T.; Yang, C.S. Effects of garcinol and its derivatives on intestinal cell growth: Inhibitory effects and autoxidation-dependent growth-stimulatory effects. Free Radic. Biol. Med. 2007, 42, 1211-1221. [CrossRef] [PubMed]

15. Koeberle, A.; Northoff, H.; Werz, O. Identification of 5-lipoxygenase and microsomal prostaglandin e2 synthase- 1 as functional targets of the anti-inflammatory and anti-carcinogenic garcinol. Biochem. Pharmacol. 2009, 77, 1513-1521. [CrossRef] [PubMed]

16. Fazio, A.; Briglia, M.; Faggio, C.; Alzoubi, K.; Lang, F. Stimulation of suicidal erythrocyte death by garcinol. Cell. Physiol. Biochem. 2015, 37, 805-815. [CrossRef] [PubMed]

17. Guidetti, G.F.; Canobbio, I.; Torti, M. Pi3k/akt in platelet integrin signaling and implications in thrombosis. Adv. Biol. Regul. 2015, 59, 36-52. [CrossRef]

18. Lang, F.; Munzer, P.; Gawaz, M.; Borst, O. Regulation of stim1/orai1-dependent ca2+ signalling in platelets. Thromb. Haemost. 2013, 110, 925-930.

19. Lannan, K.L.; Sahler, J.; Kim, N.; Spinelli, S.L.; Maggirwar, S.B.; Garraud, O.; Cognasse, F.; Blumberg, N.; Phipps, R.P. Breaking the mold: Transcription factors in the anucleate platelet and platelet-derived microparticles. Front. Immunol. 2015, 6, 48. [CrossRef]

20. Muller-Newen, G.; Stope, M.B.; Kraus, T.; Ziegler, P. Development of platelets during steady state and inflammation. J. Leukoc. Biol. 2017, 101, 1109-1117. [CrossRef]

21. Kile, B.T. The role of apoptosis in megakaryocytes and platelets. Br. J. Haematol. 2014, 165, $217-226$. [CrossRef] [PubMed]

22. Borst, O.; Schmidt, E.M.; Munzer, P.; Schonberger, T.; Towhid, S.T.; Elvers, M.; Leibrock, C.; Schmid, E.; Eylenstein, A.; Kuhl, D.; et al. The serum-and glucocorticoid-inducible kinase 1 (sgk1) influences platelet calcium signaling and function by regulation of orai1 expression in megakaryocytes. Blood 2012, 119, 251-261. [CrossRef] [PubMed]

23. Gawaz, M. Role of platelets in coronary thrombosis and reperfusion of ischemic myocardium. Cardiovasc. Res. 2004, 61, 498-511. [CrossRef] [PubMed]

24. Borst, O.; Munzer, P.; Gatidis, S.; Schmidt, E.M.; Schonberger, T.; Schmid, E.; Towhid, S.T.; Stellos, K.; Seizer, P.; May, A.E.; et al. The inflammatory chemokine cxc motif ligand 16 triggers platelet activation and adhesion via cxc motif receptor 6-dependent phosphatidylinositide 3-kinase/akt signaling. Circ. Res. 2012, 111, 1297-1307. [CrossRef] [PubMed] 
25. Bergmeier, W.; Stefanini, L. Novel molecules in calcium signaling in platelets. J. Thromb. Haemost. 2009, 7 , 187-190. [CrossRef]

26. Varga-Szabo, D.; Braun, A.; Nieswandt, B. Calcium signaling in platelets. J. Thromb. Haemost. 2009, 7, 1057-1066. [CrossRef] [PubMed]

27. Braun, A.; Varga-Szabo, D.; Kleinschnitz, C.; Pleines, I.; Bender, M.; Austinat, M.; Bosl, M.; Stoll, G.; Nieswandt, B. Orai1 (cracm1) is the platelet soc channel and essential for pathological thrombus formation. Blood 2009, 113, 2056-2063. [CrossRef]

28. Varga-Szabo, D.; Braun, A.; Nieswandt, B. Stim and orai in platelet function. Cell. Calcium. 2011, 50, $270-278$. [CrossRef]

29. Wang, Y.; Deng, X.; Gill, D.L. Calcium signaling by stim and orai: Intimate coupling details revealed. Sci. Signal. 2010, 3, 42. [CrossRef]

30. Gyulkhandanyan, A.V.; Mutlu, A.; Freedman, J.; Leytin, V. Markers of platelet apoptosis: Methodology and applications. J. Thromb. Thrombolysis 2012, 33, 397-411. [CrossRef]

31. Lebois, M.; Josefsson, E.C. Regulation of platelet lifespan by apoptosis. Platelets 2016, 27, 497-504. [CrossRef] [PubMed]

32. Mammadova-Bach, E.; Nagy, M.; Heemskerk, J.W.M.; Nieswandt, B.; Braun, A. Store-operated calcium entry in thrombosis and thrombo-inflammation. Cell Calcium. 2019, 77, 39-48. [CrossRef] [PubMed]

33. Harper, M.T.; Poole, A.W. Store-operated calcium entry and non-capacitative calcium entry have distinct roles in thrombin-induced calcium signalling in human platelets. Cell Calcium 2011, 50, 351-358. [CrossRef] [PubMed]

34. Mahaut-Smith, M.P. A role for platelet trpc channels in the ca2+ response that induces procoagulant activity. Sci. Signal. 2013, 6, 23. [CrossRef] [PubMed]

35. Mushtaq, M.; Nam, T.S.; Kim, U.H. Critical role for cd38-mediated ca2+ signaling in thrombin-induced procoagulant activity of mouse platelets and hemostasis. J. Biol. Chem. 2011, 286, 12952-12958. [CrossRef] [PubMed]

36. Lhermusier, T.; Chap, H.; Payrastre, B. Platelet membrane phospholipid asymmetry: From the characterization of a scramblase activity to the identification of an essential protein mutated in scott syndrome. J. Thromb. Haemost. 2011, 9, 1883-1891. [CrossRef]

37. Badlou, B.A.; Wu, Y.P.; Smid, W.M.; Akkerman, J.W. Platelet binding and phagocytosis by macrophages. Transfusion 2006, 46, 1432-1443. [CrossRef]

38. Smyth, S.S.; Woulfe, D.S.; Weitz, J.I.; Gachet, C.; Conley, P.B.; Goodman, S.G.; Roe, M.T.; Kuliopulos, A.; Moliterno, D.J.; French, P.A.; et al. G-protein-coupled receptors as signaling targets for antiplatelet therapy. Arterioscler Thromb. Vasc. Biol. 2009, 29, 449-457. [CrossRef]

39. Bishton, M.J.; Gardiner, E.E.; Harrison, S.J.; Prince, H.M.; Johnstone, R.W. Histone deacetylase inhibitors reduce glycoprotein vi expression and platelet responses to collagen-related peptide. Thromb. Res. 2013, 131, 514-520. [CrossRef]

40. Saadat, N.; Akhtar, S.; Goja, A.; Razalli, N.H.; Geamanu, A.; David, D.; Shen, Y.; Gupta, S.V. Dietary garcinol arrests pancreatic cancer in p53 and k-ras conditional mutant mouse model. Nutr. Cancer 2018, 70, 1075-1087. [CrossRef]

41. Cao, H.; Bhuyan, A.A.M.; Umbach, A.T.; Bissinger, R.; Gawaz, M.; Lang, F. Inhibitory effect of afatinib on platelet activation and apoptosis. Cell. Physiol. Biochem. 2017, 43, 2264-2276. [CrossRef] [PubMed]

42. Cao, H.; Bissinger, R.; Umbach, A.T.; Al Mamun Bhuyan, A.; Lang, F.; Gawaz, M. Effects of antimalarial tafenoquine on blood platelet activity and survival. Cell. Physiol. Biochem. 2017, 41, 369-380. [CrossRef] [PubMed]

43. Cao, H.; Bissinger, R.; Umbach, A.T.; Gawaz, M.; Lang, F. Temsirolimus sensitive stimulation of platelet activity, apoptosis and aggregation by collagen-related peptide. Cell. Physiol. Biochem. 2017, 42, 1252-1263. [CrossRef] [PubMed]

44. Cao, H.; Bissinger, R.; Umbach, A.T.; Gawaz, M.; Lang, F. Effect of bexarotene on platelet activation and apoptosis. Cell. Physiol. Biochem. 2017, 42, 838-847. [CrossRef] [PubMed]

45. Cao, H.; Qadri, S.M.; Lang, E.; Pelzl, L.; Umbach, A.T.; Leiss, V.; Birnbaumer, L.; Nurnberg, B.; Pieske, B.; Voelkl, J.; et al. Heterotrimeric g-protein subunit galphai2 contributes to agonist-sensitive apoptosis and degranulation in murine platelets. Physiol. Rep. 2018, 6, e13841. [CrossRef] [PubMed] 
46. Cao, H.; Umbach, A.T.; Bissinger, R.; Gawaz, M.; Lang, F. Inhibition of collagen-related peptide induced platelet activation and apoptosis by ceritinib. Cell. Physiol. Biochem. 2018, 45, 1707-1716. [CrossRef] [PubMed]

47. Honisch, S.; Gu, S.; Vom Hagen, J.M.; Alkahtani, S.; Al Kahtane, A.A.; Tsapara, A.; Hermann, A.; Storch, A.; Schols, L.; Lang, F.; et al. Chorein sensitive arrangement of cytoskeletal architecture. Cell. Physiol. Biochem. 2015, 37, 399-408. [CrossRef]

48. Liu, G.; Liu, G.; Alzoubi, K.; Chatterjee, M.; Walker, B.; Munzer, P.; Luo, D.; Umbach, A.T.; Elvira, B.; Chen, H.; et al. Cd44 sensitivity of platelet activation, membrane scrambling and adhesion under high arterial shear rates. Thromb. Haemost. 2015, 115.

49. Liu, G.; Cao, H.; Liu, G.; Heinzmann, D.; Chen, H.; Umbach, A.T.; Gawaz, M.; Lang, F. Effect of lysosomotropic polyamineoxidase inhibitor mdl-72527 on platelet activation. Cell. Physiol. Biochem. 2016, 38, 1695-1702. [CrossRef]

50. Liu, G.; Liu, G.; Chatterjee, M.; Umbach, A.T.; Chen, H.; Gawaz, M.; Lang, F. Influence of gamma-secretase inhibitor 24-diamino-5-phenylthiazole dapt on platelet activation. Cell. Physiol. Biochem. 2016, 38, 726-736. [CrossRef]

51. Liu, G.; Liu, G.; Chen, H.; Alzoubi, K.; Umbach, A.T.; Gawaz, M.; Stournaras, C.; Lang, F. Rapid upregulation of orai1 abundance in the plasma membrane of platelets following activation with thrombin and collagen-related peptide. Cell. Physiol. Biochem. 2015, 37, 1759-1766. [CrossRef] [PubMed]

52. Dong, J.; Lin, J.; Wang, B.; He, S.; Wu, C.; Kushwaha, K.K.; Mohabeer, N.; Su, Y.; Fang, H.; Huang, K.; et al. Inflammatory cytokine tslp stimulates platelet secretion and potentiates platelet aggregation via a tslpr-dependent pi3k/akt signaling pathway. Cell. Physiol. Biochem. 2015, 35, 160-174. [CrossRef] [PubMed]

53. Liu, G.; Liu, G.; Chen, H.; Borst, O.; Gawaz, M.; Vortkamp, A.; Schreiber, R.; Kunzelmann, K.; Lang, F. Involvement of ca2+ activated cl- channel ano6 in platelet activation and apoptosis. Cell. Physiol Biochem 2015, 37, 1934-1944. [CrossRef] [PubMed]

54. De Cuyper, I.M.; Meinders, M.; van de Vijver, E.; de Korte, D.; Porcelijn, L.; de Haas, M.; Eble, J.A.; Seeger, K.; Rutella, S.; Pagliara, D.; et al. A novel flow cytometry-based platelet aggregation assay. Blood 2013, 121, e70-e80. [CrossRef] [PubMed] 